\title{
QUANTITATIVE MORPHOMETRIC AND HYPSOMETRIC ANALYSIS USING REMOTE SENSING AND GIS TECHNIQUES
}

\author{
M. Shivaswamy \\ Research Scholar, Research Centre, RV College of Engineering, Bangalore, India. \\ A.S. Ravikumar \\ Associate Professor, Department of Civil Engineering, \\ University Visvesvaraya College of Engineering, Jnanabharathi, Bangalore, India.

\section{B.L. Shivakumar} \\ Professor and Head, Department of Civil Engineering, \\ Jnana Vikas Institute of Technology Bidadi, Ramanagara, Karnataka, India.
}

\begin{abstract}
Water and land are limited natural resources to be distributed among all equitably. Rainfall is the main source of runoff. The accurate estimate of available water resource is required to meet the raising demand for water from different sectors. Morphometric parameters and runoff estimation help in appropriate planning for, optimum utilization of water, conservation, recharging of the ground water zones, reducing the soil erosion and management of floods. The study area chosen is Kabini Command area spreads in Mysore and Chamarajnagara districts. It is located between $76^{\circ} 12^{\prime} 0^{\prime \prime} E$ and $77^{\circ} 12^{\prime} 0^{\prime \prime}$ E longitude and $11^{\circ} 58^{\prime} 0^{\prime \prime} \mathrm{N}$ and $12^{\circ} 16^{\prime} 0^{\prime \prime} \mathrm{N}$ with an area of $5985.48 \mathrm{~km}^{2}$ and is covered in Survey of India (SOI) Top sheet number 57H04, 57H03, 57D16, 58E01, 58A13, 57D12, 57D08, 58A05 and 58A01 on 1:50000 scale. Remote sensing and GIS techniques are used to delineate the entire catchment into 7 watersheds. Morphometric analysis is carried out at the watershed level to understand the hydrological process and to derive the inferences from the watershed parameters. The bifurcation ratio ranges between 4 to 5 which shows the geological structure do not distort drainage pattern. The drainage density varies from 1.49 to $2.65 \mathrm{~km} / \mathrm{km}^{2}$ indicating the area is coarse and moderate in texture. Watershed is more elongated as the elongation ratio ranges from 0.34 to 0.42 . Hypsometric analysis is done for the catchment to reveal the stages of geomorphic development. Hypsometric integral quantifies the geological stages of development and erosion proness of Kabini command area. Hypsometric integral has estimated by graphical plot of measured contour elevation and encompassed area by using empirical formulae.
\end{abstract}

Key words: GIS, Hypsometry, Morphometry, Remote sensing, Thematic maps. 
Cite this Article: M. Shivaswamy, A.S. Ravikumar and B.L. Shivakumar, Quantitative Morphometric and Hypsometric Analysis Using Remote Sensing and GIS Techniques, International Journal of Advanced Research in Engineering and Technology, 10 (4), 2019, pp 1-14.

http://iaeme.com/Home/issue/IJARET?Volume $=10 \&$ Issue $=4$

\section{INTRODUCTION}

Water and land are the limiting natural resources. The per capita availability being decreased due to growing population. The availability of fresh water is being reduced in different sectors, proper planning and management of water is the need of the hour to achieve sustainable development. A watershed is an area from which runoff resulting from precipitation flows and joins a single point to form large stream, a lake, river or ocean. Thus a watershed is the surface area drained by a part or the totality of one or several given water courses and can be taken as basic erosional landscape element where land and water resources interact in a perceptible manner (Sebastian et al., 1995). Morphometry is the measurement and mathematical analysis of configuration of the earth surface, shape and dimensions of its landforms (Clarke, 1996). The term morphometry is derived from a Greek word, where "morpho" means earth and "metry" means measurement, so together it is measurement of earth features. Morphometric analysis provides quantitative description of the basin geometry to understand initial slope or inequalities in the rock hardness, structural controls, geological and geomorphic history of drainage basin (Strahler, 1964). The goal of the study is to establish quantitative, rather than qualitative relationships between geomorphic processes and landforms. Morphometric analysis provides quantitative description of basin geometry to understand initial slope or inequalities in rock hardness, structural controls, recent diastrophism, geological and geomorphic history of a drainage basin (Strahler, 1964). The goal of study is to establish quantitative, rather than qualitative relationships between geomorphic processes and land forms. Morphometric analysis of watershed provides quantitative description of the drainage system which is an important aspect of characterization of watersheds (Strahler, 1964). The influence of drainage morphometric is very significant in understanding the land form processes and erosional characteristics. Remote sensing (RS) and geographical information systems (GIS) techniques have been used for assessing various terrain and morphometric parameters of the drainage basins and watersheds as they provide a flexible environment and a powerful tool for the manipulation and analysis of spatial information particularly for the feature identification and extraction of information for better understanding.

Hypsometric analysis aims at developing area relationship between horizontal crosssectional area of the watershed and its elevation in a dimensionless form that permits comparison of watersheds irrespective of scale issues (Dowling et al., 1998). Hypsometric curves (HC) and Hypsometric integrals are important indicators of watershed conditions (Ritter et al., 2002). Differences in shape of curve and hypsometric integral value are related to degree of disequilibrium in the balance of erosive and tectonic forces (Weissel et al, 1994). Hypsometric analysis was first time introduced by Langbein in 1947 to express overall slope and forms of drainage basin. The hypsometric curve is related to the volume of soil mass in the basin and the amount of erosion that had occurred in the basin against the remaining mass (Hurteez et al., 1999 a). It is a continuous function of non-dimensional distribution of relative basin elevations with the relative area of the drainage basin (Strahler 1952) comparison of the shapes of the hypsometric curve for different drainage basin under similar hydrologic conditions provides relative insight into the soil moment of basins. Thus the shape of the hypsometric curve explains to temporal changes in the slope of the original basin Strahler 
(1952) interpreted the shapes of the hypsometric curves by explaining numerous drainage basins and classified the basins as young (convex upward curves) mature (S-S shaped hypsometric curves which is concave upwards at higher elevations and convex downwards at low elevations) and pediplain are distorted (concave upwards curves). These hypsometric curve shapes described the stages of the landscape evolution which also provide an indication of erosion status of the watershed. Convex shaped hypsometric curves indicate more proneness of watershed to erosion process (Hurteez et al., 1999 b). Hypsometric curve and hypsometric integral are important watershed health indicators.

\section{STUDY AREA}

The area chosen is Kabini command area. It is spread in Mysore and Chamaraj nagar districts. The study area geographically lies between $76^{\circ} 12^{\prime} 0^{\prime \prime} \mathrm{E}$ and $77^{\circ} 12^{\prime} 0^{\prime \prime} \mathrm{E}$ longitude and $11^{\circ}$ $58^{\prime} 0^{\prime \prime} \mathrm{N}$ and $12^{0} 16^{\prime} 0^{\prime \prime} \mathrm{N}$ with an area of $5985.48 \mathrm{~km}^{2}$. And is covered in Survey of India (SOI) Toposheet numbers 57H04, 57H03, 57D16, 58E01, 58A13, 57D12, 57D08, 58A05 and 58A01 on 1:50000 scale. The maximum length and width of the command is approximately equal to $97.40 \mathrm{~km}$ and $37.00 \mathrm{~km}$ respectively. River Kabini is a major tributary to river Cauvery and has its origin in Western Ghats of Wayanad of Kerala state and flows for a length of $212 \mathrm{~km}$ before joining the river Cauvery at Tirumakudalu Narasipura, Karnataka State. The Kabini dam is constructed across river Kabini between Bidarahlli village on right bank and Beechanahalli village on left bank in Heggadadevanakote taluk, Mysore district. Fig. 1 shows the location map of study area.

Data Products:

- SOI Top maps on 1:50000 scale

- Rainfall data from KSNMDC, Bengaluru

- Hydro meteorological data from WRDO, Bangalore

- Soil Data from KSRAC. Bengaluru

- IRS-2 Resource -SAT imagery

\section{METHODOLOGY}

\subsection{Preparation of base map and thematic maps:}

A common base map is prepared from SOI Topomaps on 1:50,000 scale. The base map provides the basic details such as the command boundary, latitude, longitude, major roadway, railway, rivers/ stream, water bodies, taluk boundaries, location of important settlements, etc.which serves as control points during the interpretation of remotely sensed data. (Fig.2)

Drainage map is prepared for the study area using SOI Topomaps on 1:50,000 scale and updated with remotely sensed data. The recent development of water bodies, streams are mapped using remotely sensed data. The watersheds are delineated based on the topography and drainage pattern (Fig. 3). The drainage map is used for morphometric analysis to understand the hydrological process and to derive inferences of the command at the watershed level.

Land use/land cover map is prepared to furnish the information based on existing development and pattern of their spatial distribution using remotely sensed data. Interpretation is carried out up to level II classification. There are 27 classifications in Level-II. Fig. 4 shows level II land /land cover classifications. Table 1 shows the spatial distribution of land use/land cover classification at watershed level. 


\subsection{Morphometric Analysis}

In the present study, the morphometric analysis is carried out at watershed level. The watershed is delineated within the command area based on topography and drainage pattern.

These morphometric parameters are useful in understanding the hydrological process of the drainage basin. The analysis is carried out through measurements of linear, areal and relief aspects of these watersheds.

\subsubsection{Linear aspect}

Linear aspects include the measurements of linear features of drainage such as stream order, stream length, Bifurcation ratio, mean stream length, stream length ratio. The allocation of the stream order is based on hierarchic ranking of streams. If the drainage network (i.e., the arrangement of stream channels) of watershed is efficient, water will flow rapidly and will result in higher peak, as the concentration time is less. Hence, the more efficient is the drainage, the flashier the stream flow will be, and vice-versa.

\subsubsection{Areal Aspects}

Areal aspects $(\mathrm{Au})$ of a watershed of given order $\mathrm{u}$ is defined as the total area projected upon a horizontal plane contributing overland flow to the channel segment of the given order and includes all tributaries of lower order. Areal aspects include different morphometric parameters, like drainage density, texture ratio stream frequency, form factor, circulatory ratio elongation ratio and length of the overland flow.

\subsubsection{Relief aspects}

Relief aspects are important factors in understanding the extent of denudation process undergone within the catchment and it is indicator of flow direction of water. Table 2 shows the formulae used for morphometric analysis.

\subsubsection{Hypsometry}

The hypsometric analysis for the seven watersheds of Kabini command carried out using ArcInfo and ArcGIS tools. A hypsometric curve is the relationship between horizontal crosssectional areas and altitudes of the watersheds. The hydrological response of watersheds to precipitation events depends on mechanisms of runoff generation in particular on the partitioning between surface and sub-surface discharge to the channel network. Topography place a significant role in determining the basin response. The dominant runoff mechanisms can also impact the outcome of errosional process on landscape form.

The hydrological process depends on many basin properties, the relief ratio and catchment volume play important roles in determining runoff. The relief ratio indicates over all steepness of a basin and controls lateral water redistribution, while the catchment volume which is defines as the amount of mass above a datum provides a measure of storage capacity and determines locations of ground water seepage.

The relief ratio and catchment volume can be concisely captured through the hypsometric curve. The hypsometry curve is typically represented as distribution of the relative height $(\mathrm{h} / \mathrm{H})$ with relative area $(\mathrm{a} / \mathrm{A})($ Strahler 1952).

Hypsometric curves and hypsometric integrals are important indicators of watershed condition (Ritter et al., 2002). Differences in the shape of the curve and the hypsometric integrals values are related to the degree of disequilibria in the balance of erosive and tectonic forces (Weissel et al., 1994). Comparison of the shapes of the hypsometric curve for different drainage basins under similar hydrogeological condition provides a relative insight in to the history of soil movement of basins. Strahler (1952) interpreted the shapes of the hypsometric curves by analyzing numerous drainage basins and classified the basins as youth (convex upward curves) mature ( $\mathrm{S}$ shaped hypsometric curves which is concave upwards at high 
elevations and convex downwards at low elevations) and peneplain or distorted (concave upwards curves). These hypsometric curve shapes described the stages of landscape evolution which also provides an indication of erosion status of watershed. Convex shaped hypsometric curves indicate that the watershed is stabilized and the concave hypsometric curve more proneness of watershed to the erosion processes (Hurtrez et al., 1999).

The hypsometric integral (HI) is geo-morphological parameter classified under the geologic stages of watershed development. It assumes importance in estimation of erosion status of watershed and subsequent prioritization for taking up soil and water conservation activities. The HI is expressed as a percentage, and is an indicator of remnant of the present volume as compared to the original volume of the basin (Ritter et al., 2002). The hypsometric integrals help in explaining the erosion that had taken place in the watershed during the geological time scale due to hydrologic processes and land degradation factors (Bishop et al., 2002). Hypsometric curve and hypsometric integral are important watershed health indicators (Awasti et al., 2002). The hypsometric analysis of all the seven watersheds of Kabini command is carried out.

\section{RESULTS AND DISCUSSIONS}

The morphometric parameters estimated on watershed wise and the values for the entire command. Table 3 shows the different morphometric parameters estimated.

According to the study the highest stream order obtained is $7^{\text {th }}$ order and hence designated as $7^{\text {th }}$ ordered catchment. The total length of stream segments is maximum in the first order and decreases as the stream order increases. The pattern of drainage is dendritic the mean stream length of any given order is greater than that of the lower order but less than that of the next higher order. In the present case the values of $R_{b}$ varies from 3.77 to 4.626 (less than 5) for the watersheds; 4.89 for the entire catchment and hence these have suffered any structural disturbances. The drainage density reflects the land use, affects the infiltration and watershed response time between precipitation and discharge. The drainage density of the area varies from 1.49 to $2.65 \mathrm{~km} / \mathrm{km}^{2}$ indicating that the area is moderate to coarse texture. Stream frequency value for the catchment is 2.06 and for watersheds its value varies from 1.26 to 3.60 this indicates that the stream frequency is low.

The circularity ratio varies from 0.22 to 0.57 for the watersheds and 0.28 for the catchment. Its low, medium and high values are correlated with youth, mature and old stage of the tributary of the watershed in the region.

The elongation ratio ranges for the catchment is 0.34 to 0.42 which indicates that the catchment is more elongated and all watersheds have elongation ratio lower than 0.50 which indicates more elongated watersheds.

The total relief of the catchment is $0.5 \mathrm{~km}$ and the values of relief for the watersheds vary from $0.13 \mathrm{~km}$ to $1.14 \mathrm{~km}$ which indicates that the watershed has enough slopes for the runoff to occur from the remote point of the watershed to mouth. The relative relief ratio for the catchment is 0.0027 and for watersheds it ranges from 0.00142 to 0.00591 . The high relative relief indicates that it is composed of resistant rock patches and low relief ratio indicates less resistant patch of rocks.

Morphometric parameters such as stream order, stream length, number of streams, bifurcation ratio, drainage density, stream frequency are estimated for all the watersheds to understand the hydrological process of the catchment. The morphometric analysis of the drainage networks of the watersheds of the study area shows dendritic patterns with course to moderate drainage texture. The bifurcation ratio of watersheds indicates normal basin category and the presence of low drainage density suggesting that it has highly permeable sub-soil and coarse drainage texture. The values of stream frequency indicate that all the 
watersheds show positive correlation with increasing stream population with respect to increasing drainage density. The values of form factor and circulatory ratio suggest that most of the watersheds are elongated. Higher bifurcation ratio values are characteristic of the catchment that have suffered more structural disturbance, and the drainage pattern has not been distorted in the catchment.

The hypsometric curve for all the seven watersheds is represented in figures 5 to 11 . In the present study hypsometric integral is estimated using elevation relief ratio method proposed by Pike and Wilson (1971). The relationship is expressed as

$$
H I=\frac{E_{w t}-E_{\text {min }}}{E_{\max }-E_{\min }}
$$

Where $\mathrm{E}$ is the elevation relief ratio equitant to the hypsometric integral $\mathrm{HI}, \mathrm{E}_{\mathrm{wt}}$ is the weighted mean Elevation of the watershed estimated from the identifiable contours of the delineated watershed, $E_{\min }$ and $E_{\max }$ elevations within the watershed. The HI for the watersheds worked out is tabulated in the table 4.

Surface runoff and sediment losses are two important hydrologic responses from the rainfall events occurring over the watershed systems. The hypsometric integral value can be an indirect estimator of the erosion from the watershed systems. It is observed from the HI values in Table 4 that the watersheds and their sub basins are in mature and monadnock phase or pedieplanation or the deteriorating stage.

The study reveals $16-27 \%$ of the rock masses still exists in these watersheds. The watersheds attaining mature stage will have slow rate of erosion unless there are high intense storms leaning to high run off peaks. It is observed that Doddahole watershed is in mature stage and all other watershed are in monadnock phase. The hypsometric integral values can be used for watershed prioritisation to take up conservation measures. Here the HI values are less than 0.5 i.e., approaching monadnock phase needs minimum mechanical and vegetative measures to arrest sediment loss but may require more water harvesting type structure to conserve water at appropriate location in the watersheds for conjunctive use of water.

\section{FIGURES AND TABLES}

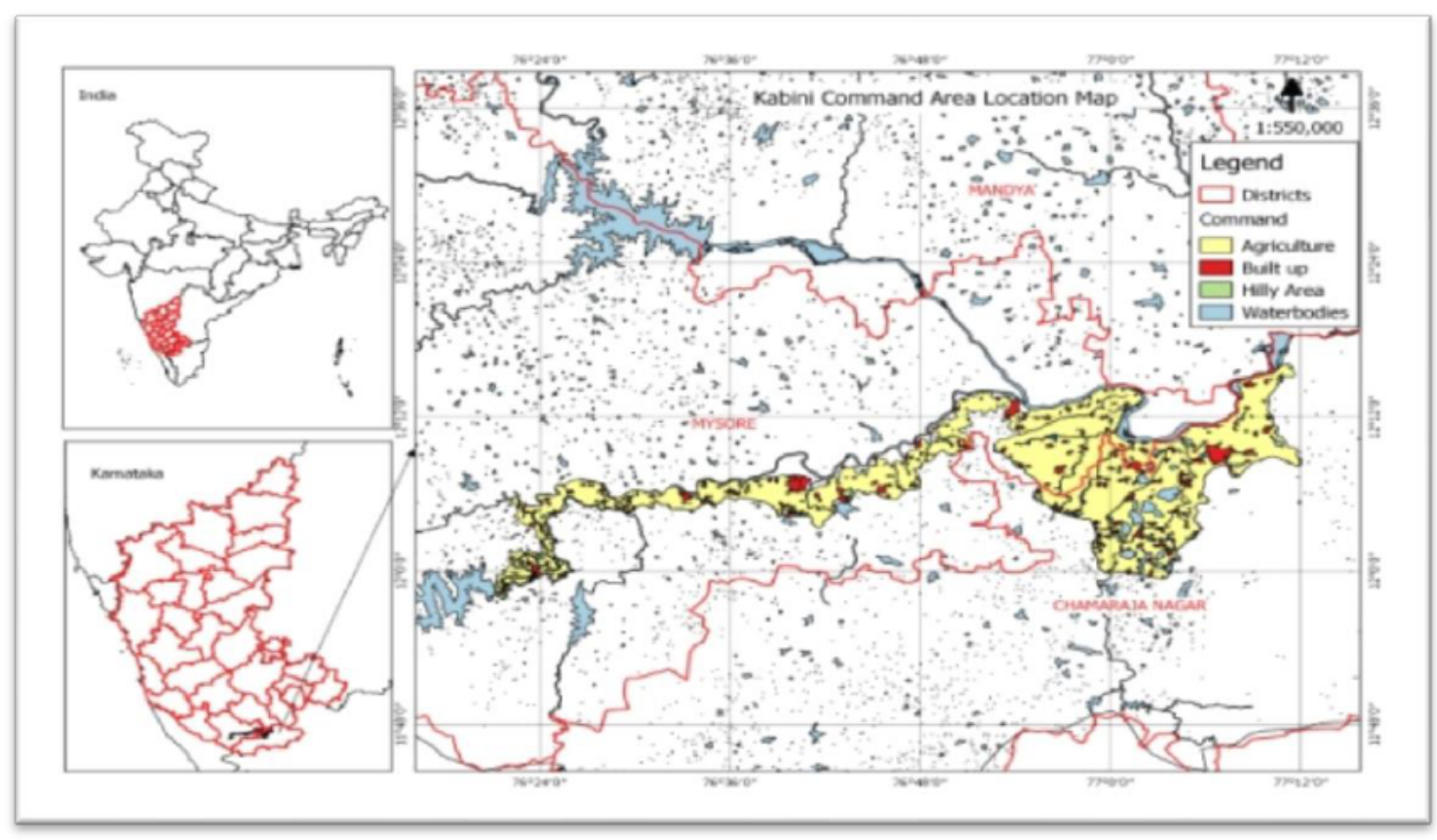

Figure 1 Location Map of Kabini Command area 
Quantitative Morphometric and Hypsometric Analysis Using Remote Sensing And GIS Techniques

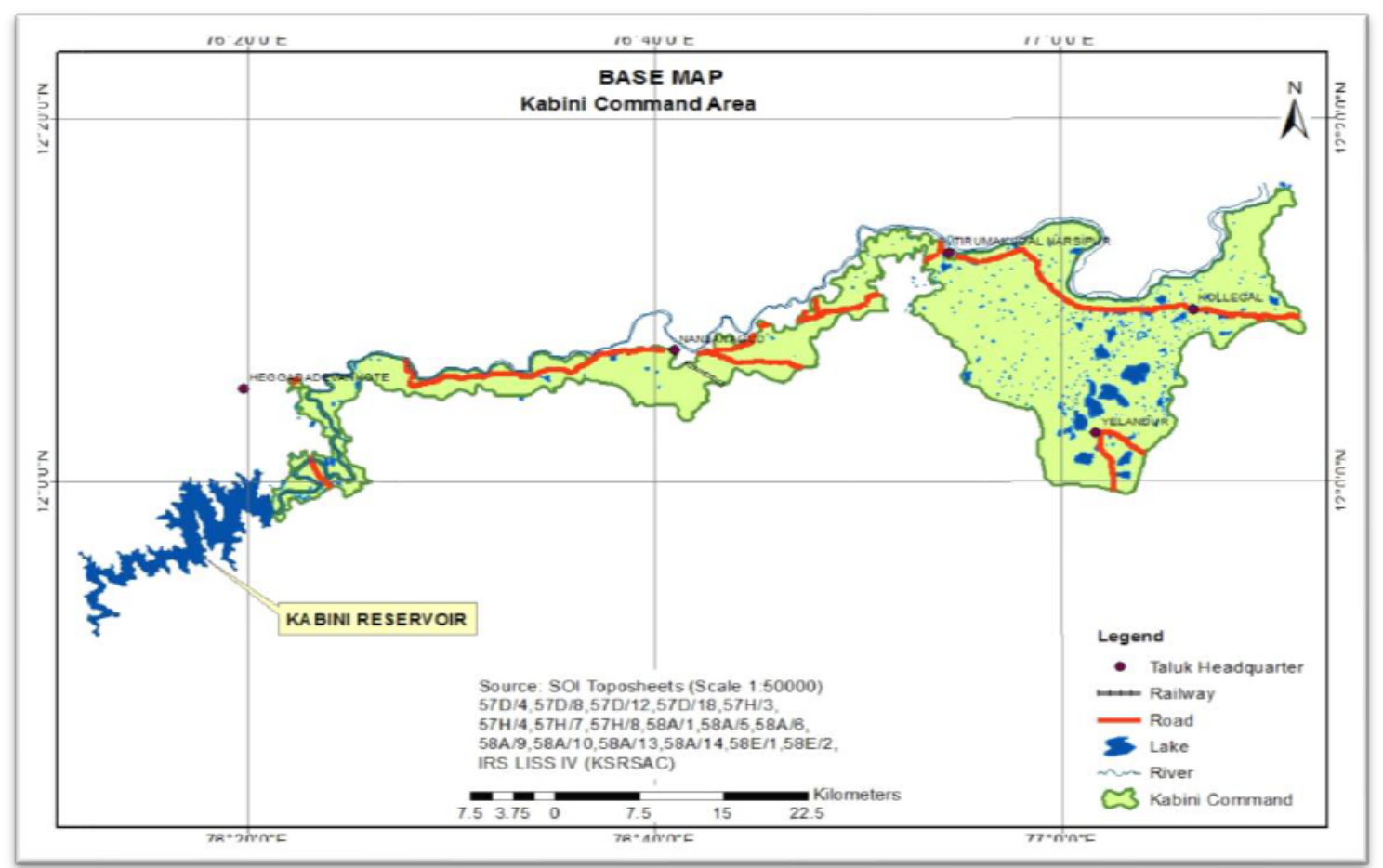

Figure 2 Base Map of Kabini command area

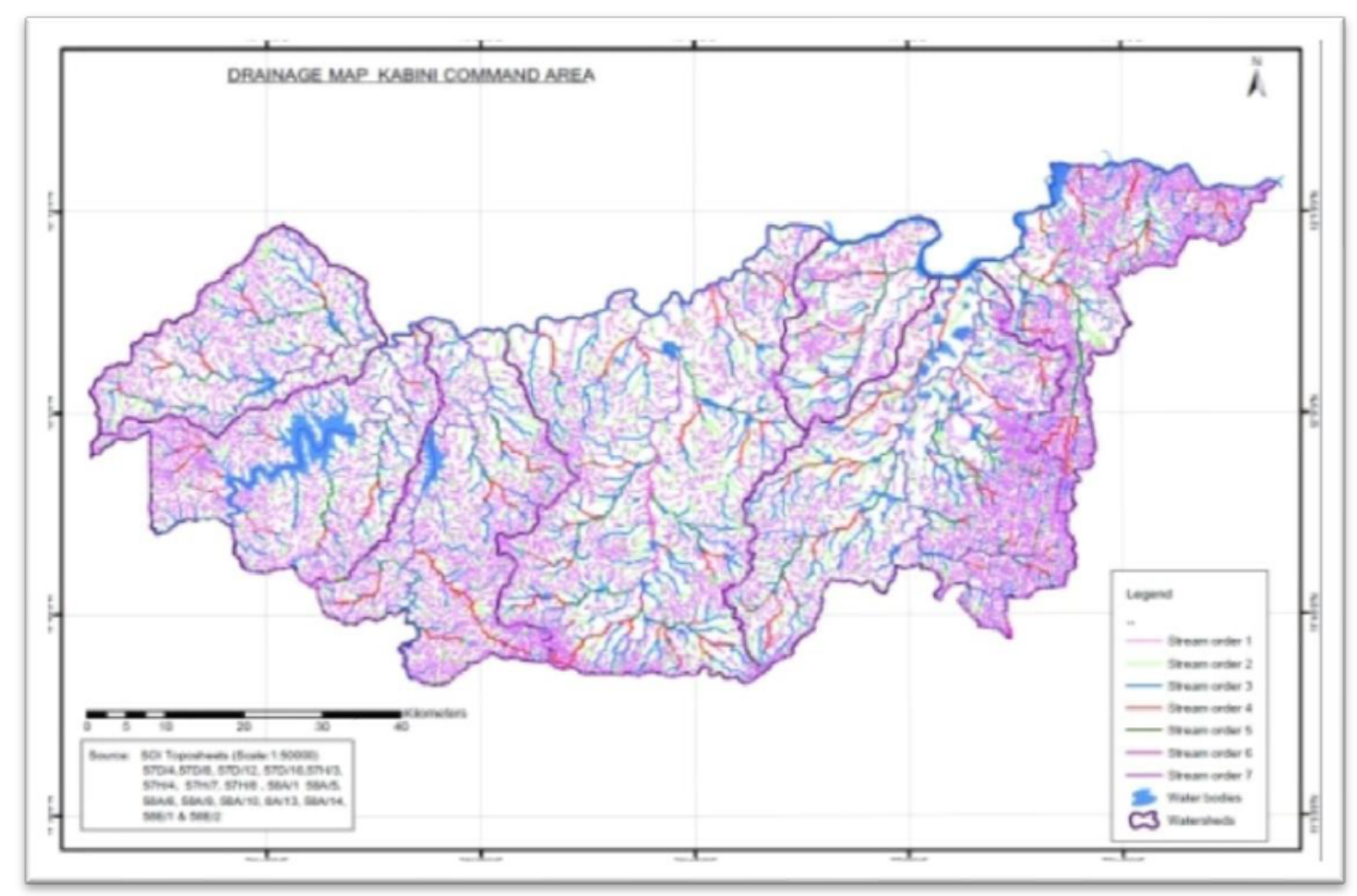

Figure 3 Drainage Map of Kabini Command Area 


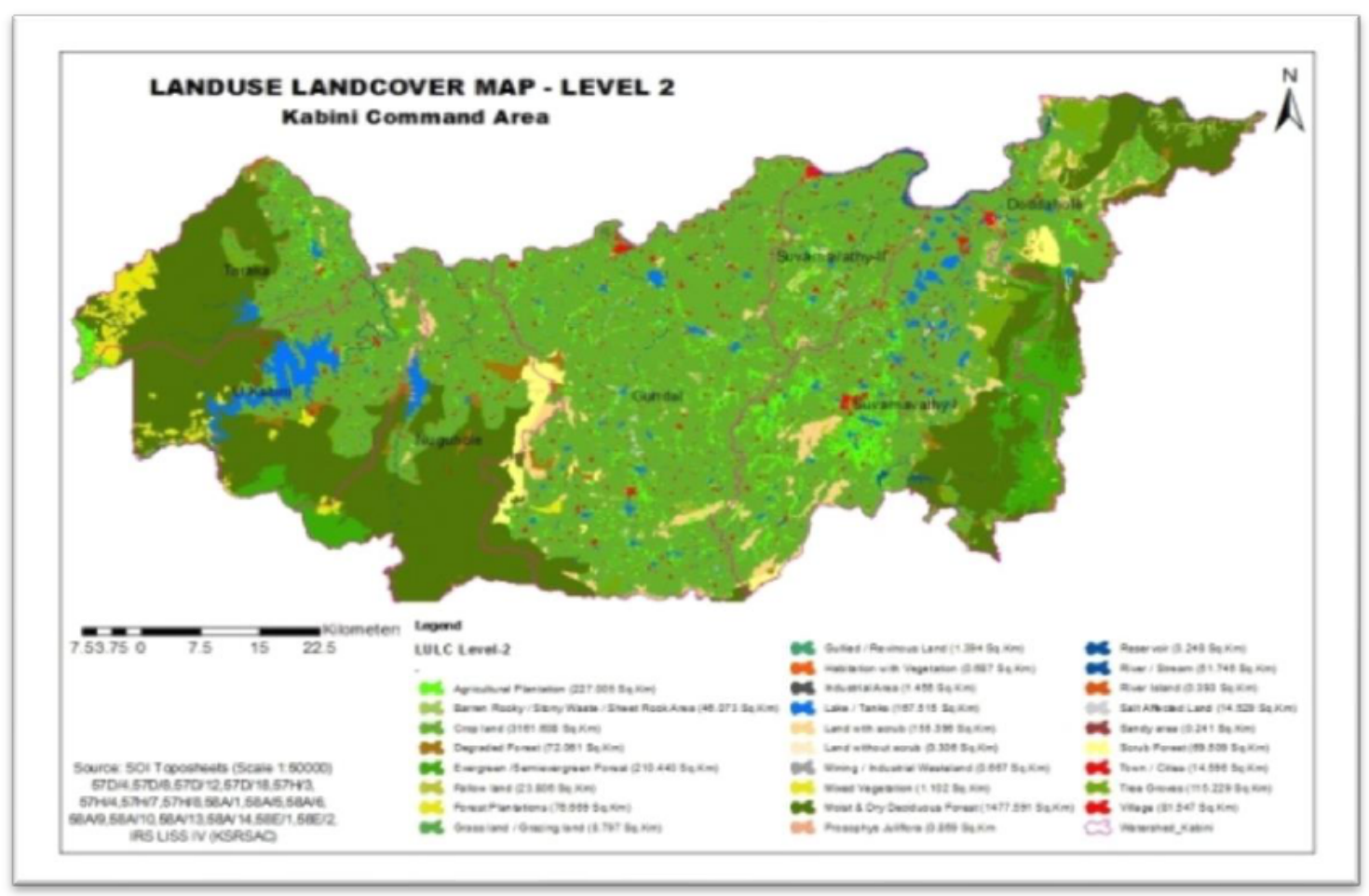

Figure 4 Land use/Land cover Level II classification of Kabini command catchment.

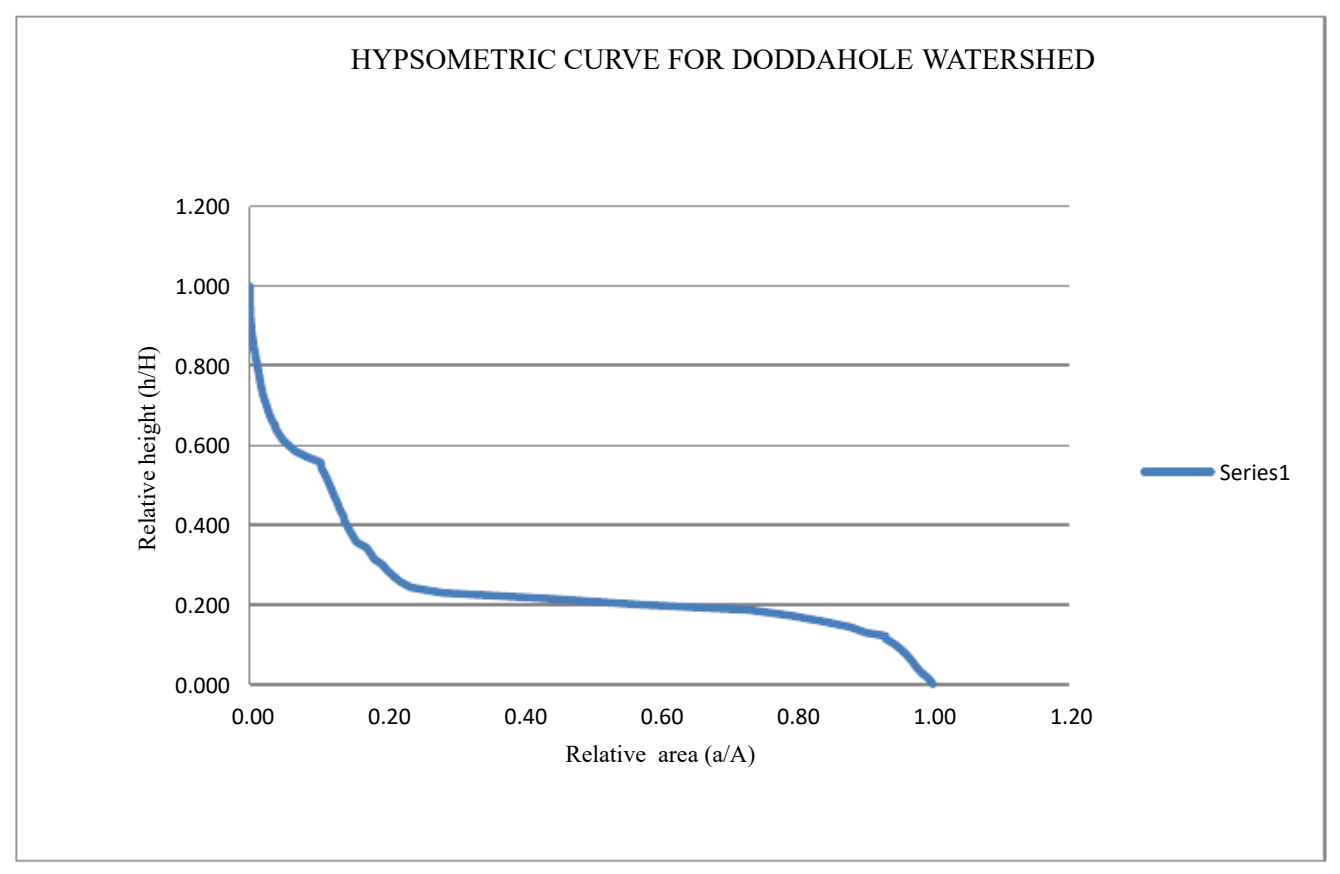

Figure 5 Hypsometric curve for Doddahole Watershed 
Quantitative Morphometric and Hypsometric Analysis Using Remote Sensing And GIS Techniques

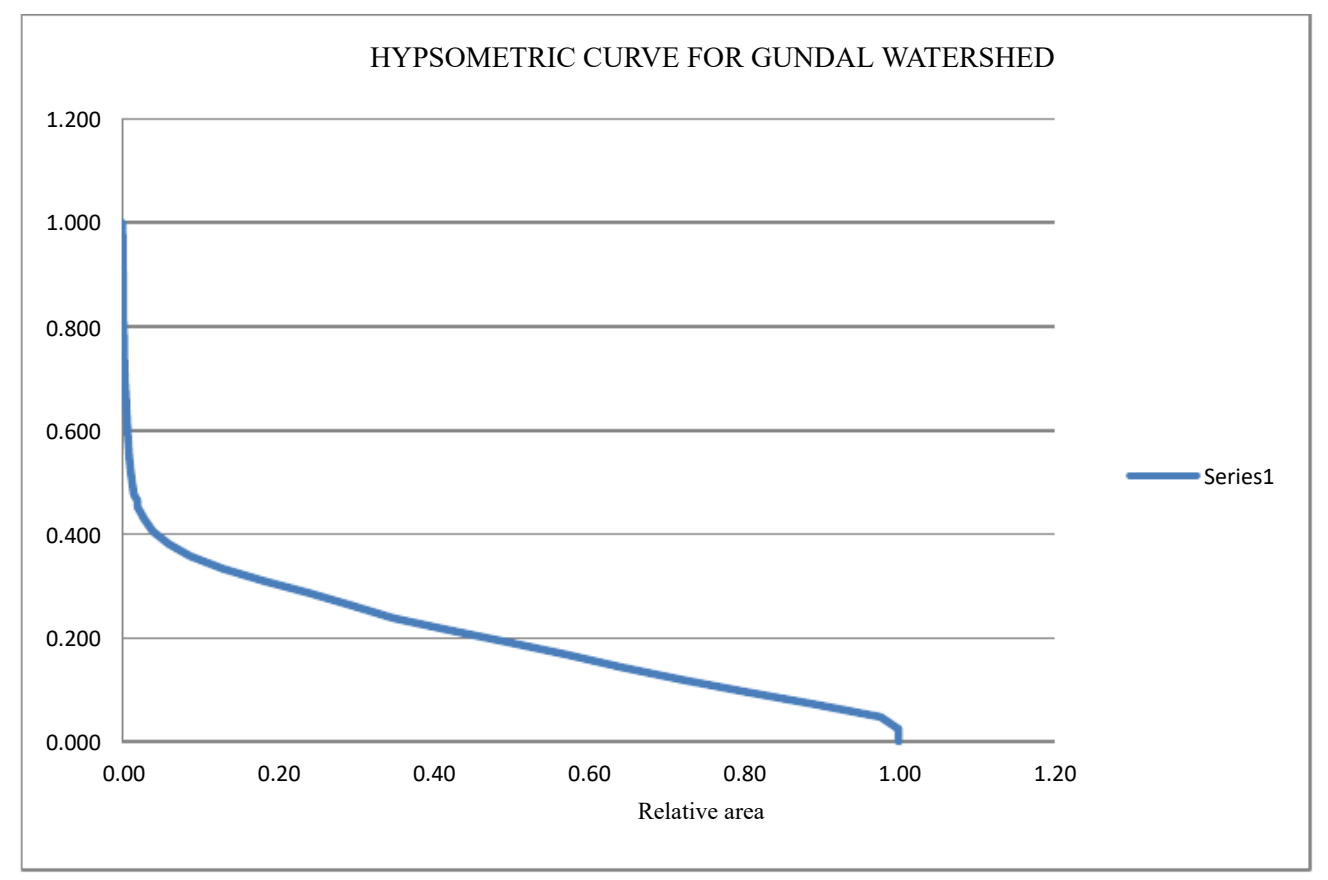

Figure 6 Hypsometric curve for Doddahole Watershed.

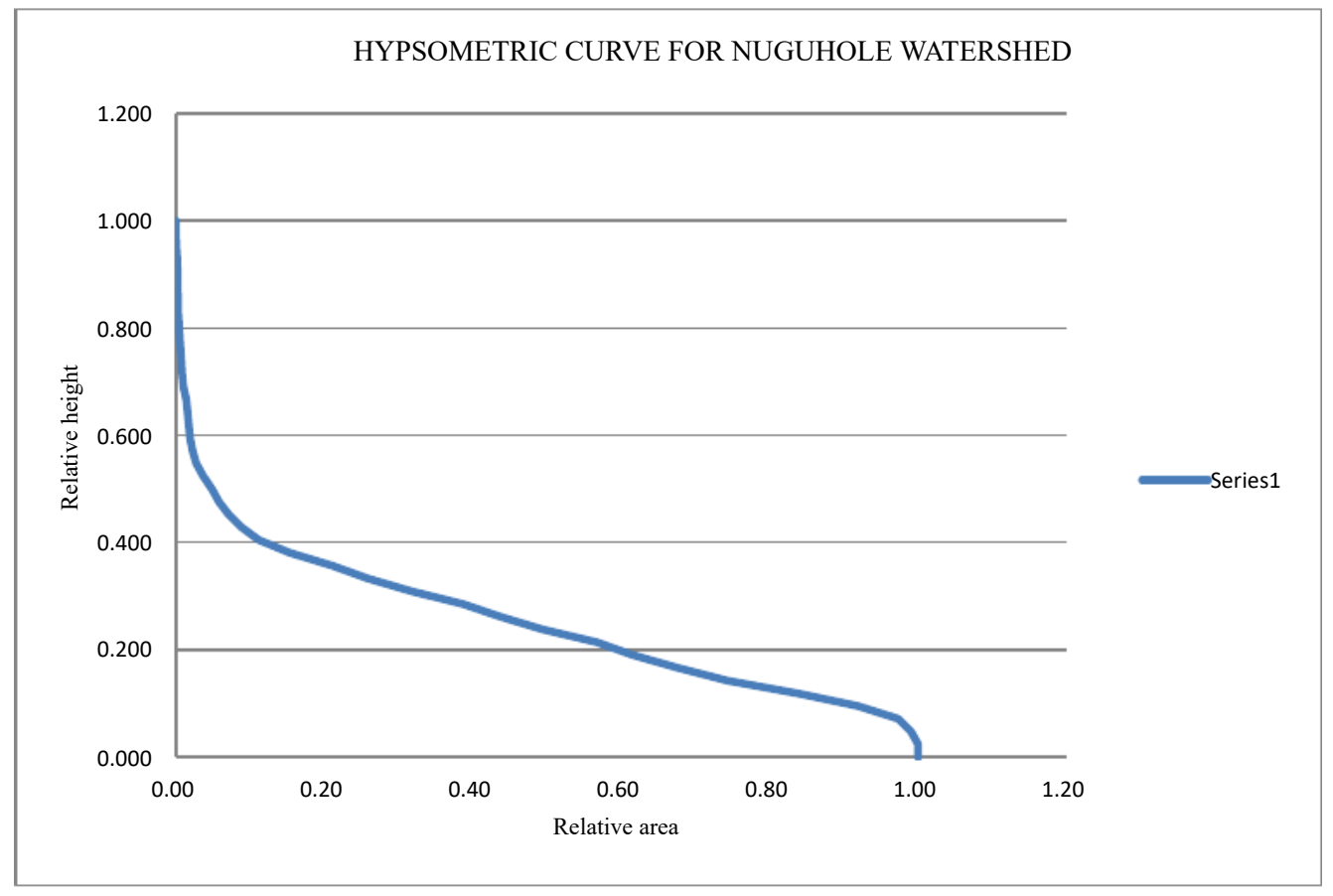

Figure 7 Hypsometric curve for Nuguhole Watershed. 
M. Shivaswamy, A.S. Ravikumar and B.L. Shivakumar

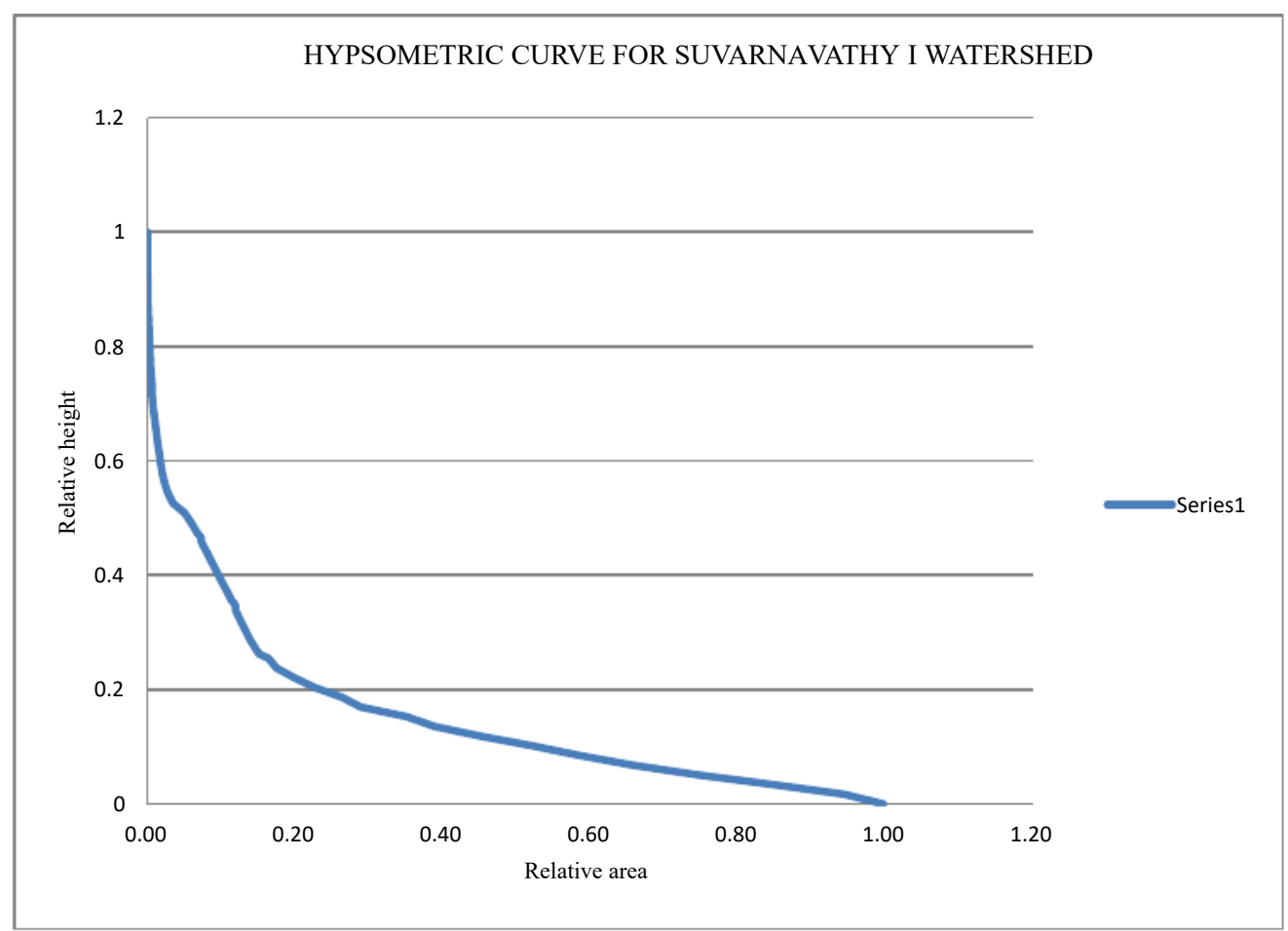

Figure 8 Hypsometric curve for Suvarnavathy I Watershed.

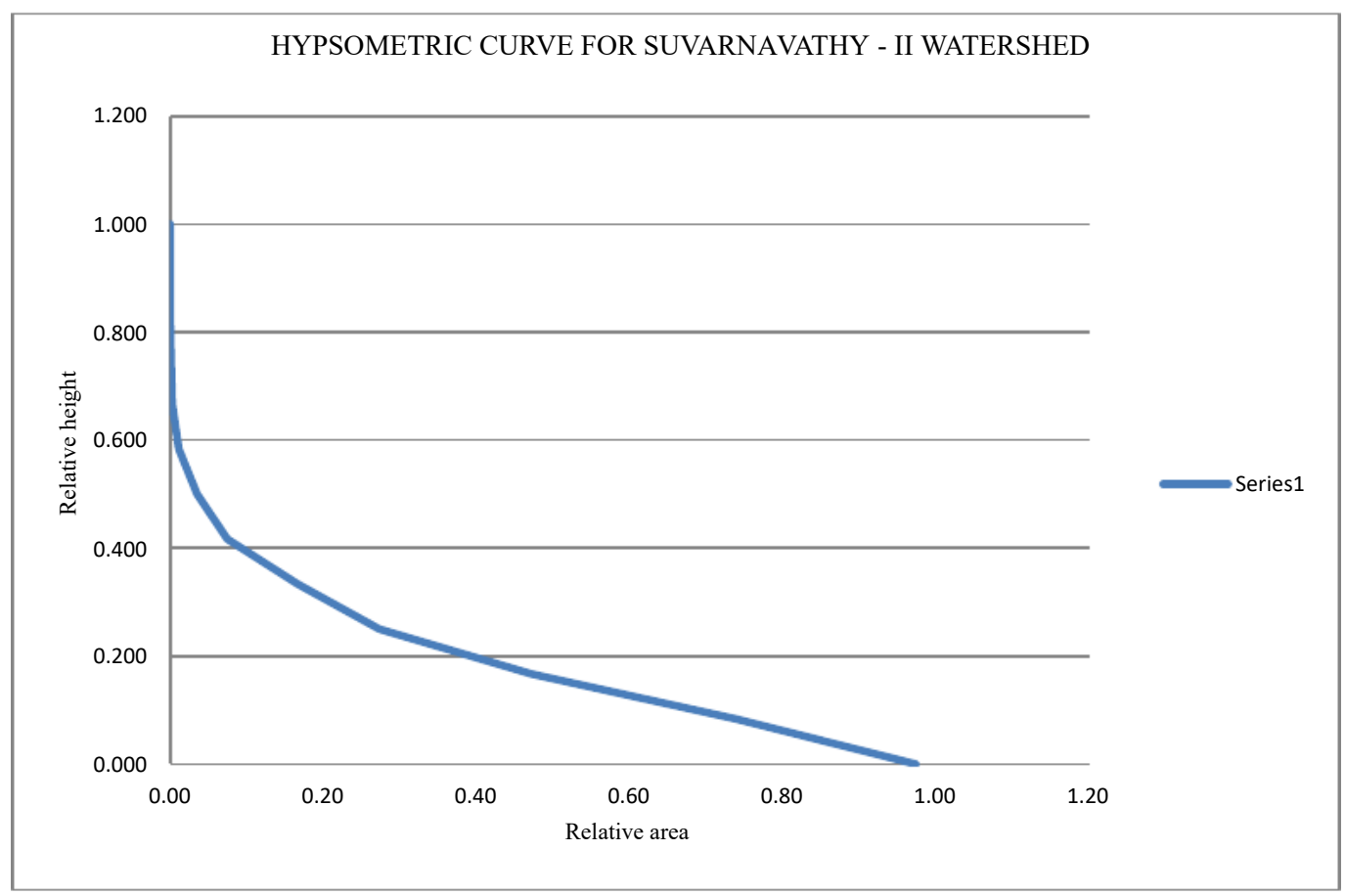

Figure 9 Hypsometric curve for Suvarnavathy II Watershed. 


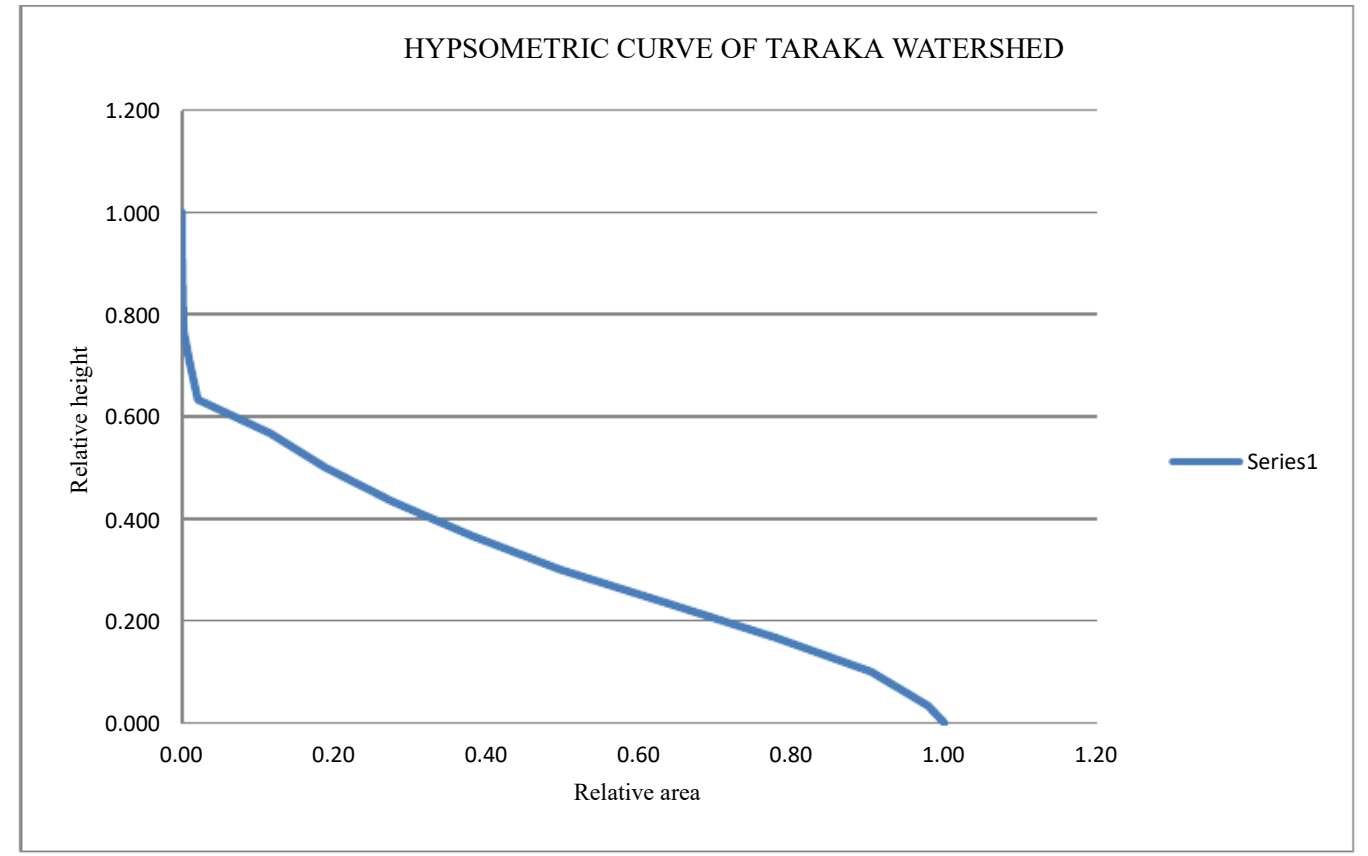

Figure 10 Hypsometric curve for Taraka Watershed.

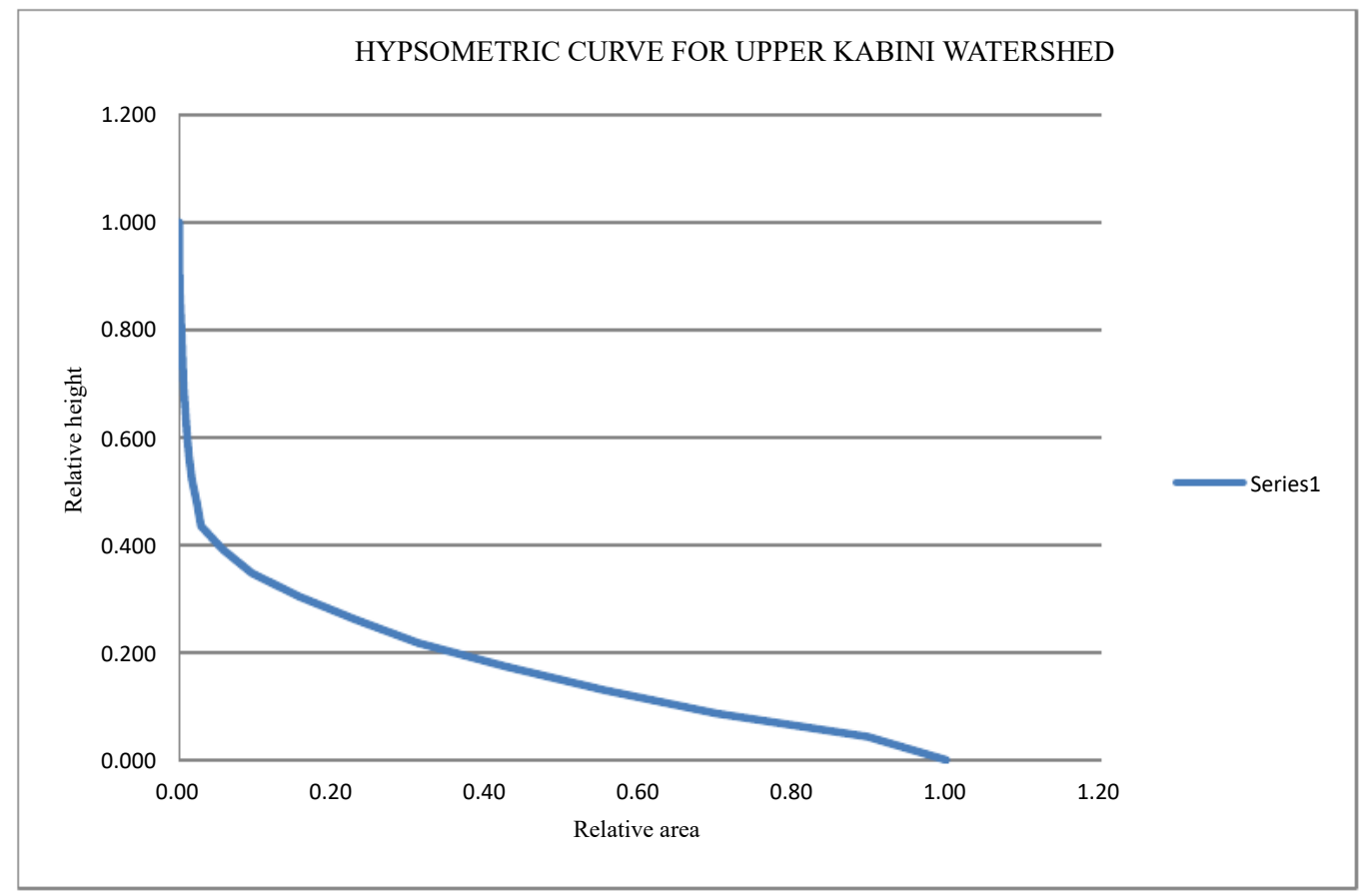

Figure 11 Hypsometric curve for Upper Kabini Watershed.

Table 1 Spatial distribution of Land use/land cover of Kabini Command Area

\begin{tabular}{|c|c|c|c|}
\hline SI No & Land Use and Land Cover & Area $\left(\mathbf{K m}^{\mathbf{2}}\right)$ & \% of Area \\
\hline 1 & Agricultural plantation & 227.01 & 3.79 \\
\hline 2 & Barran rocky/stony wate/sheet rock areas & 46.07 & 0.77 \\
\hline 3 & Crop land & 3161.61 & 52.82 \\
\hline 4 & Degraded Forest & 72.06 & 1.20 \\
\hline 5 & Evergreen/Semi evergreen forest & 210.44 & 3.52 \\
\hline 6 & Fallow land & 24.81 & 0.41 \\
\hline 7 & Forest plantations & 76.67 & 1.28 \\
\hline 8 & Grass land/grassing land & 8.80 & 0.15 \\
\hline
\end{tabular}


M. Shivaswamy, A.S. Ravikumar and B.L. Shivakumar

\begin{tabular}{|c|c|c|c|}
\hline 9 & Gullied/ ravenous land & 1.39 & 0.02 \\
\hline 10 & Habitation with vegetation & 0.69 & 0.01 \\
\hline 11 & Industrial area & 1.46 & 0.02 \\
\hline 12 & Lakes/tanks & 167.52 & 2.80 \\
\hline 13 & Land with scrub & 155.40 & 2.60 \\
\hline 14 & Land without scrub & 0.31 & 0.01 \\
\hline 15 & mining/ industrial waste land & 0.67 & 0.01 \\
\hline 16 & Mixed vegetation & 1.10 & 0.02 \\
\hline 17 & Moist and dry deciduous forest & 1477.59 & 24.69 \\
\hline 18 & Prosophys juliflora & 0.87 & 0.01 \\
\hline 19 & Reservoir & 3.25 & 0.05 \\
\hline 20 & River stream & 51.75 & 0.86 \\
\hline 21 & River island & 0.39 & 0.01 \\
\hline 22 & Salt affected land & 14.53 & 0.24 \\
\hline 23 & Sandy area & 0.24 & 0.00 \\
\hline 24 & Scrub forest & 69.51 & 1.16 \\
\hline 25 & Town/cities & 14.60 & 0.24 \\
\hline 26 & Tree groves & 115.23 & 1.93 \\
\hline 27 & Village & 81.55 & 1.36 \\
\hline & Total & 5985.48 & 100 \\
\hline
\end{tabular}

Table 2 Formulae used for morphometric parameters.

\begin{tabular}{|c|c|c|c|}
\hline S1. No & Morphometric parameters & Formula & Reference \\
\hline 1 & Stream order & Hierarchical rank & Strahler (1964) \\
\hline 2 & Stream length $\left(\mathrm{L}_{\mathrm{u}}\right)$ & Length of the stream & Horton (1945 \\
\hline 3 & Mean stream length $\left(\mathrm{L}_{\mathrm{sm}}\right)$ & $L_{s m}=L_{u} / N_{u}$ & Strahler (1964) \\
\hline 4 & Stream length ratio $\left(\mathrm{R}_{\mathrm{f}}\right)$ & $R_{1}=L_{u} / L_{(u-1)}$ & Horton (1945) \\
\hline 5 & Bifurcation ratio $\left(\mathrm{R}_{\mathrm{b}}\right)$ & $R_{b}=N_{u} / N_{(u+1)}$ & Schumn (1956) \\
\hline 6 & Mean Bifurcation ratio $\left(\mathrm{R}_{\mathrm{bm}}\right)$ & $R_{b m}=$ Average of bifurcation ratios of all \\
orders & Strahler (1957) \\
\hline 7 & Relief ratio $\left(\mathrm{R}_{\mathrm{h}}\right)$ & $R_{h}=H / L_{b}$ & Schumn (1956) \\
\hline 8 & Drainage density $(\mathrm{D})$ & $D=L_{u} / A$ & Horton (1932) \\
\hline 9 & Stream frequency $\left(\mathrm{F}_{\mathrm{s}}\right)$ & $F_{s}=N_{u} / A$ & Horton (1932) \\
\hline 10 & Form factor $\left(\mathrm{R}_{\mathrm{f}}\right)$ & $R_{f}=A / L_{b}$ & Horton (1932) \\
\hline 11 & Circularity ratio $\left(\mathrm{R}_{\mathrm{c}}\right)$ & $R_{c}=(4 * \pi * A)^{1 / 2} / p^{2}$ & Miller $(1953)$ \\
\hline 12 & Elongation ratio $\left(\mathrm{R}_{\mathrm{e}}\right)$ & $R_{e}=2(A / \pi)^{1 / 2} / L_{b}$ & Schumn (1956) \\
\hline
\end{tabular}

Table 3 Morphometric parameters for the Kabini Command Area.

\begin{tabular}{|c|c|c|c|}
\hline SI No. & Parameters & Units & Value \\
\hline 1 & Area & $\mathrm{km}^{2}$ & 5985.48 \\
\hline 2 & Perimeter & $\mathrm{km}$ & 543.64 \\
\hline 3 & Length of Watershed & $\mathrm{km}$ & 64.74 \\
\hline 4 & Width of Watershed & $\mathrm{km}$ & 156.23 \\
\hline 5 & Total no of Segments & $\mathrm{km}$ & 12376.00 \\
\hline 6 & Total length of Stream segments & & 089.29 \\
\hline 7 & Mean Length & & 7 \\
\hline 8 & Highest Order of Stream & & 4.89 \\
\hline 9 & Bifurcation ratio & 2.17 \\
\hline 10 & Stream Length Ratio & 1.43 \\
\hline 11 & Form factor & & 0.70 \\
\hline 12 & Shape factor & & 0.70 \\
\hline 13 & Elongation ratio & 1.90 \\
\hline 14 & Compactness Coefficient & 0.28 \\
\hline 15 & Circularity ratio & & 2.07 \\
\hline 16 & Stream Frequency & \\
\hline
\end{tabular}


Quantitative Morphometric and Hypsometric Analysis Using Remote Sensing And GIS Techniques

\begin{tabular}{|c|c|c|c|}
\hline 17 & Drainage density & $\mathrm{km} / \mathrm{km}^{2}$ & 1.82 \\
\hline 18 & Drainage texture & & 22.77 \\
\hline 19 & Constant of Channel maintenance & & 0.55 \\
\hline 20 & Length of overland flow & & 0.30 \\
\hline 21 & Difference in Elevation & $\mathrm{km}$ & 0.55 \\
\hline 22 & Watershed relief & & 0.01 \\
\hline 23 & Relative relief & & 0.30 \\
\hline
\end{tabular}

Table 4 Hypsometric integral of seven watersheds of Kabini command.

\begin{tabular}{|c|c|c|c|c|c|}
\hline SI No & $\begin{array}{c}\text { Name of Water } \\
\text { shed }\end{array}$ & $\begin{array}{c}\text { Max Elevation } \\
\left(\mathbf{E}_{\text {max }}\right)\end{array}$ & $\begin{array}{c}\text { Min Elevation } \\
\left(\mathbf{E}_{\text {min }}\right)\end{array}$ & $\begin{array}{c}\text { Wt elevation } \\
\left(\mathbf{E}_{\mathbf{w t}}\right)\end{array}$ & $\boldsymbol{H I}=\frac{\boldsymbol{E}_{\boldsymbol{w} \boldsymbol{t}}-\boldsymbol{E}_{\boldsymbol{m i n}}}{\boldsymbol{E}_{\boldsymbol{m a x}}-\boldsymbol{E}_{\boldsymbol{m i n}}}$ \\
\hline 1 & Doddahole & 1750 & 350 & 715.45 & 0.26 \\
\hline 2 & Gundal & 1430 & 590 & 771.47 & 0.22 \\
\hline 3 & Suvarnavathi 1 & 1790 & 610 & 800.41 & 0.16 \\
\hline 4 & Suvarnavathi 2 & 850 & 610 & 665.02 & 0.23 \\
\hline 5 & Taraka & 980 & 680 & 766.09 & 0.29 \\
\hline 6 & Upper Kabini & 1110 & 650 & 740.73 & 0.20 \\
\hline 7 & Nuguhole & 1430 & 610 & 831.69 & 0.27 \\
\hline
\end{tabular}

\section{SUMMARY AND CONCLUSIONS}

The drainage pattern of the study area is dendritic, the highest stream order is seventh order and hence designated as seventh order watershed. The drainage density reveals that the soils of the area is having moderate to coarse texture with highly permeable sub soil. The watersheds are elongated having relief indicating enough slope for runoff to occur. The bifurcation ratio indicates the watersheds have suffered more structural disturbances and the drainage pattern has not been distorted.

The HI values are less than 0.5 i.e., approaching monadnock phase needs minimum mechanical and vegetative measures to arrest sediment loss but may require more water harvesting type structure to conserve water at appropriate location in the watersheds for conjunctive use of water. The hypsometric curve of the watersheds is less prone to soil erosion as they have reached monadnock phase.

\section{ACKNOWLEGEMENT}

The authors are very much grateful to Water Resources Development Organization (WRDO) and Karnataka State Natural Disaster Monitoring Centre (KSNDMC), Govt of Karnataka, Bengaluru for sparing spatial data and non-spatial data for the research work.

\section{REFERENCES}

[1] Awasthi K D, Situla B K, Singh BR, Bajacharaya R M, Land-use changes in twomNepalese watersheds: GIS and geomorphometric analysis. Land DegradDev 13, 2002, pp 495-513

[2] Bishop MP, Shroder JF, Bonk R, Olsenhollrr J, Geomorphic change in high mountains: a western Himalayan persective. Globe Planet Change 32, 2002, pp 311-329

[3] Clarke, J.I, "Morphometry from Maps, Essays in Geomorphology”, Elsevier Publ. Co., New York, 1966, pp. 235-274.

[4] B N Suma, C V Srinivasa, A Study on Morphometric Parameter of a Watershed for Sustainable Water Conservation. International Journal of Civil Engineering and Technology, 8(9), 2017, pp. 271-278 
[5] Dowling TI, Richardson DP, O'Sullivan A, Summerell GK, Walker J, Application of the hypsometric integral and other terrain based metrices as indicators of the catchment health: a preliminary analysis Technical report 20/98.CSIRO Land and, 1998

[6] Hurtrez, J.E, Lucazean, F., J and Avouac, J.P, Investigation of the relationship between basin morphology, tectonic uplift and denudation from the study of an active fold belt in Siwalik Hills (Central Nepal). Journal of Geophysical Research 104, 1999, pp 779-796.

[7] Pike, R.J. and Wilson, S.E, Elevation-relief ratio, hypsometric integral and geomorphic areaaltitude analysis. Geological Society of America Bulletin 82, 1971, pp.1079-1084.

[8] Mohammad O. Alagha, Saud A. Gutub and Amro M. Elfeki, Estimation of NRCS curve number from watershed morphometric parameters: A Case Study of Yiba Watershed in Saudi Arabia, International Journal of Civil Engineering and Technology, 7(2), 2016, pp. 247-265.

[9] Ritter, D.F, Kochel, R.C and Miller, J.R, Process Geomorphology. McGraw Hill: Boston, 2002

[10] Sebastian, M., Jayaraman, V., and Chandrasekhar, M.G, "Space Technology Applications for Sustainable Development of Watersheds", Technical Report, Indian Space Research Organization Bangalore, 1995

[11] Indranil Singh, Ruchi Khare., Morphometric Analysis of Rajgardh Watershed of Madhya Pradesh, International Journal of Civil Engineering and Technology, 8(4), 2017, pp. 13191328

[12] Strahler, A.N, Quantitative geomorphology of drainage basins and channel network. In handbook of Applied Hydrology, Chow VT Ed., McGraw Hill: New York. 1964, Pp.39-76.

[13] Morphometric Analysis on Precambrian Rocks in Part of Cauvery Basin, Chamarajanagar District, Karnataka, India, Using Geomatics Technique, Basavarajappa H.T., Pushpavathi K.N and Manjunatha M.C, International Journal of Civil Engineering and Technology (IJCIET), Volume 6, Issue 1, January (2015), pp. 97-112

[14] Strahler, A.N, Hypsometric (area-altitde) analysis of erosional topography. Geological Society of America Bulletin 63, 1952, pp. 1117-1141.

[15] K. Ilayaraja, Morphometric Parameters of Micro Watershed in Paravanar Sub-Basin, Cuddalore District. International Journal of Civil Engineering and Technology, 8(8), 2017, pp. 1444-1449.

[16] Weissel, J.K., Pratson, L.F and Malinverno, A, The length scaling properties of topography. Journal of Geophysical Research 99, 1994, pp.13997-14012. 